\title{
Potential and impact study of Amman high frequency speed bus, a case study
}

\author{
Ashraf Samarah', Afaq Hiary ${ }^{2}$, Ameera Amayira ${ }^{3}$, Heba Asheesh ${ }^{4}$, Ayman Y. Al-Rawashdeh $^{5}$ \\ 1,2,3,4 Department of Electrical Engineering, Al-Balqa Applied University, Jordan \\ ${ }^{5}$ Department of Electrical Engineering, Faculty of Engineering Technology, Al-Balqa Applied University, Jordan
}

\begin{tabular}{|c|c|}
\hline Article Info & ABSTRACT \\
\hline Article history: & The current study proposes the utilization of solar panels to power high \\
\hline Received May 27, 2018 & Photo Voltaic technology, mounting PV solar panels system on the top of \\
\hline Revised Apr 3, 2019 & the track of the high frequence bus, arranged at azimuth angle ranging \\
\hline Accepted Apr 9, 2019 & $\begin{array}{l}\text { between } 0^{\circ}-90^{\circ} \text { with the best tilt angle measured } 12^{\circ} \text {, along an actual } \\
\text { unshaded trak of } 18 \mathrm{~km} \text { (of the } 25 \mathrm{~km} \text { total pathway track), resulted in }\end{array}$ \\
\hline Keywords: & $\begin{array}{l}\text { the generation of more than } 18 \mathrm{MWp} \text { (On Grid system). Such power is used } \\
\text { not only to charge the bus and to operating facilities inside the city instead of } \\
\text { the conventional ways as illustrated in the coming later. }\end{array}$ \\
\hline
\end{tabular}

Electrical buses

Photovoltaic systems

Copyright () 2019 Institute of Advanced Engineering and Science. All rights reserved.

\section{Corresponding Author:}

Ashraf Samarah,

Department of Electrical Engineering,

Al-Balqa Applied University,

Asalt- Assalt-Jordan,

Fax: +962-5-353065

Email: samarah@bau.edu.jo

\section{INTRODUCTION}

Smart cities are often pictured as a collection of variable modern instruments across many scales that are connected through multiple networks that are able to provide continuous data regarding the movements of people and objects. Cities are considered smart only when, such intelligent functions are able to integrate and synthesize this continuous flow of data in a way designed to improve the efficiency, equity, sustainability and quality of life.

Energy efficiency improvement is one of the most important specifications of smart cities. Today, almost $80 \%$ of the global energy supply is consumed in most cities and according to the International Energy Agency (IEA) predictions energy consumption will continue to grow up to 56\% between 2010 and 2040. Considering factors like the urbanization processes, unsustainable lifestyles, and global consumption patterns followed by each society, the relationship between energy and city is one of the biggest challenges that urban planners must consider around the world. There is a great interest on in the Nearly-Zero Energy Buildings (NZEB), that are designed to produce equal amounts of energy they consume. Despite the difficulties for their implementation, the use of renewable energy resources to reduce energy loads in cities, is so essential to achieve the NZEB goal and it provides a significant contribution to a sustainable energy portfolio in the present and future.

Public transportation nowadays is one of the most encountered daily challanges in most modern cities of the world. Problems like fuel world crisis, traffic congestions and pollution and other environmental problems renewed the interest of public transportation as a solution, especially if designed to use reneweable environment friendly energy resources $[1,2]$. In fact, public transportations utilizing electrical buses are 
nowadays considred a main reason for significant reduction of $\mathrm{CO}_{2}$ emission [3]. One solution to this problem is the implementation of electrical Bus Rapid Transit (BRT). Electrical transportation is now considered a major strategy in many countries, aimed to reduce the use of fossile fuels and their negative impact on environment [4]. During the last two years, electric buses received renewed interest world wide $[5,6]$.

BRT is a high performance rapid-transit mode that merges a combination of physical, operating and system elements into a long-term integrated system with a quality image and unique identity. This BRT can solve the public transportation problem by controlling and reducing the arrival time to the desired destination, avoiding traffic congestion.

In Jordan, great efforts were designed to solve the growing population problems in the capital Amman. One proposed solution was the Amman BRT Figure 1 [7, 8], which has a high-capacity run on exclusive and completely segregated lines and currently is underway on one of the city's main arteries [7]. Due to many factors in the capital city, the corridors of the BRT are incorporated into an integrated public transportation network. This means that one needs more than more than just a BRT ride to reach their destination. Therefore, an extensive network of Feeder services is being designed along with the BRT. Such feeders will mostly be Buses or small vehicles for carrying the passengers to their nearest BRT stop [2]. BRT routes are divided into two lines as shown in Figure 2. Table 1 shows the exact routes of the high frequency speed bus and its corresponding distances.

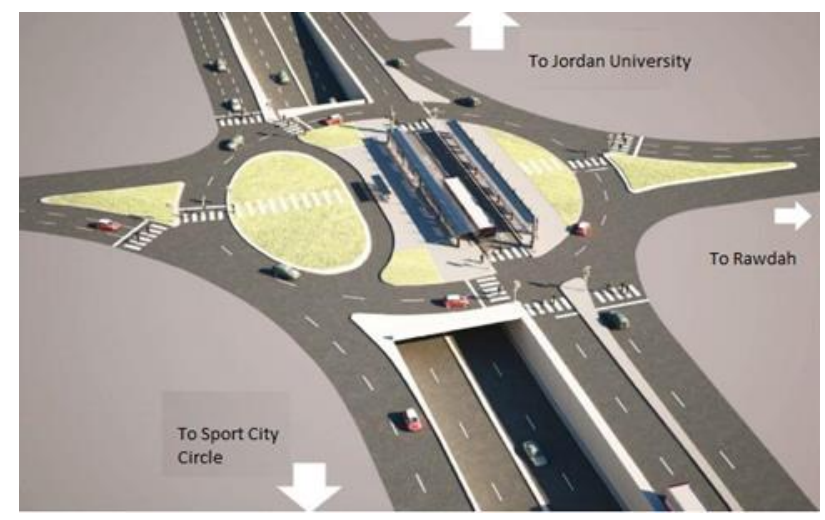

Figure 1. The general design of BRT in the tunnel of the press - Amman, Jordan

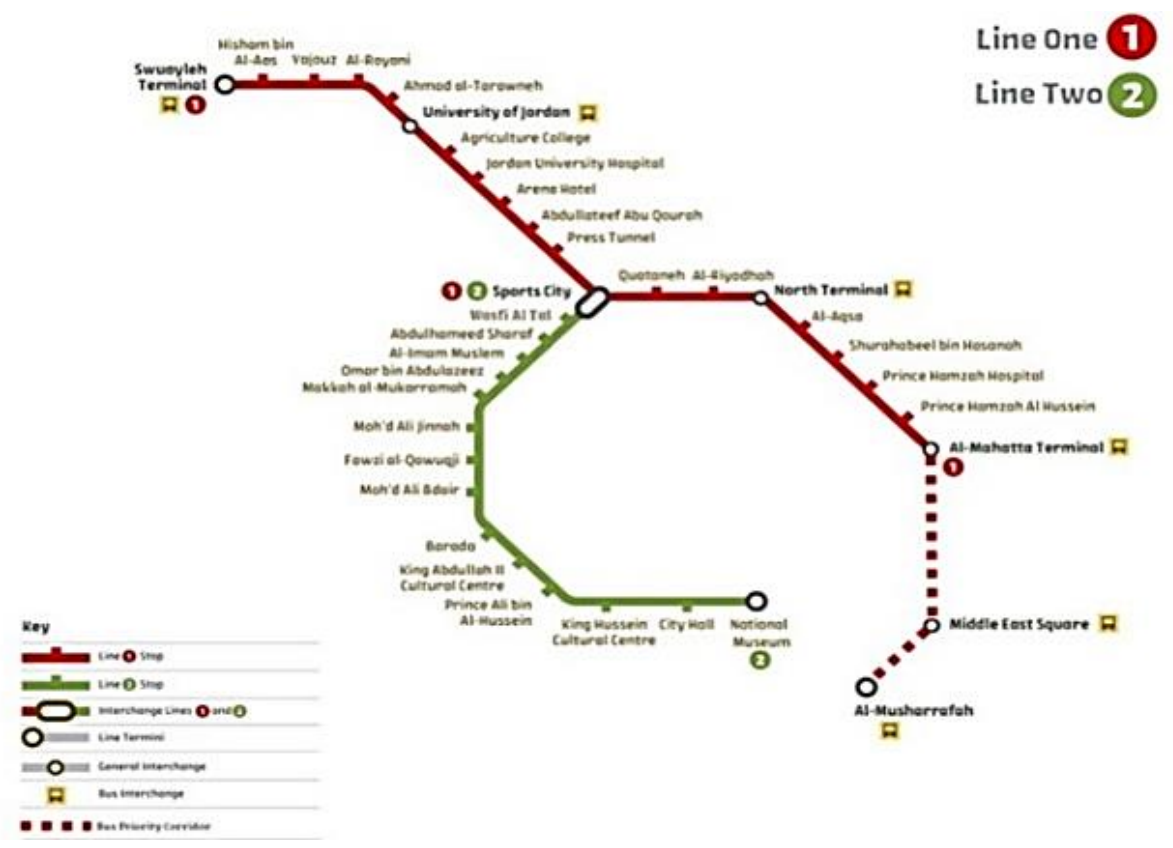

Figure 2. Rout of the BRT in Amman City 
Table 1. BRT routs and their distances $(\mathrm{km})$ in the capital of Jordan-Amman City

\begin{tabular}{clc}
\hline \multicolumn{1}{c}{ The routes } & Distance $(\mathrm{km})$ \\
\hline 1 & Queen Rania Al Abdullah Street & 2.1 \\
2 & Princess Basma Street & 4.0 \\
3 & University of Jordan & 1.5 \\
4 & Yagouz intersection & 1.0 \\
5 & Al-Aqsa Street & 3.0 \\
6 & Al-Kindi Street & 1.3 \\
7 & Al Shaheed Street & 3.0 \\
8 & Omar Matar Street & 1.5 \\
9 & Fountain Square & 1.0 \\
10 & Al Shareef Nasir Bin Jameel Street & 2.5 \\
11 & Almahtta station & - \\
12 & Istiklal Street & 2.5 \\
13 & Press tunnel & 1.0 \\
14 & Sports city & 0.8 \\
15 & Sweleih station & 1.2 \\
16 & Al Yarmouk Street & 8.0 \\
\hline
\end{tabular}

However, in its current form, the BRT (commonly known as Rapid Bus) utilizes diesel as a fossile fuel. The current investigation suggests the utilization of solar panels mounted at the top of the trak not only to charge the BRT, but also for other purposes. Despite that the total distance of the BRT rout is $25 \mathrm{~km}$, the perfect and suitable shadow fredd distance is only $18 \mathrm{~km}$, is found in fact enough to generate a power exceeding $18 \mathrm{MWp}$ (on grid system). Arranging the panels with streets scale produced an azimuth angle ranging between $0^{\circ}-90^{\circ}$ and the best tilt angle was measured as $12^{\circ}$.

\section{PHOTO VOLTAIC TECHNOLOGY}

To support the proposed bus by electricity, a large source of power is needed since the distance is $25 \mathrm{Km}$ for the 3 phases as shown in Table 4. This proposed distance is a proper distance to build such a PV system, which can provide the needed power to charge and operate the BRT. There are many factors that affect the performance characteristics and the output power of the solar panels among which, shade was considered the main one. Since the rout of the BRT passes though builidhgs and trees, shade will affect the mounted panels and lower their expected outputs. Hence, an actual field study of the the BRT path led us to excluded the shaded area. Based on the actual field evaluation, it was found that the real unshaded distance along the proposed BRT rout was $18.5 \mathrm{~km}$ out of the $25 \mathrm{~km}$ of the total route. Table 2 lists the basic data for the unshaded rout and the charactersitics of the solar panels proposed.

Table 2. Basic data

\begin{tabular}{ll}
\hline Total distance & $18.5 \mathrm{~km}$ \\
Width of each line & $7 \mathrm{~m}$ \\
Bus height & $3.35 \mathrm{~m}$ \\
Tilt angle & $12.0^{\circ}$ \\
Azimuth & Depends on the route \\
Panels module & JA solar panels $/ 330 \mathrm{w}_{\mathrm{p}}$ \\
Panels dimensions & $(1,2) \mathrm{m}$ \\
\hline
\end{tabular}

One of the factors that affect the performance and the output power of the solar panels was the irradiation which changed from one place to another due to longitude and the altitude changes. Figure 3 shows the irradiation in Amman city. There were three suggestions (A, B \& C) for the structure and scale of the proposed solar panels, these are shown in Figure 4. The total power out put for these cases was: A (8.2 MW), B (10.989 MW) and C (18.315 MWp). Case C, which afforded the maximum power was considered the best choice for the current investigation. 


\begin{tabular}{|c|c|c|c|c|c|}
\hline \multicolumn{2}{|l|}{$\begin{array}{l}\text { Amman } \\
\text { Jordan }\end{array}$} & \multicolumn{2}{|c|}{ Source of climatic data } & \multicolumn{2}{|c|}{ NASA-SSE } \\
\hline Latitude & $31.95^{\circ}$ & \multirow{2}{*}{$\begin{array}{l}\text { Longitude } \\
\text { T Min }\end{array}$} & $35.94^{\circ}$ & \multirow[t]{2}{*}{ Altitude } & \multirow[t]{2}{*}{$757.0 \mathrm{~m}$} \\
\hline T Max & $45.0^{\circ} \mathrm{C}:$ & & $-5.0^{\circ} \mathrm{C}:$ & & \\
\hline \multicolumn{6}{|c|}{ Monthly average irradiance on horizontal plane } \\
\hline \multicolumn{2}{|l|}{ Month } & \multicolumn{2}{|c|}{ Global $\left[\mathrm{kWh} / \mathrm{m}^{2}\right]$} & \multicolumn{2}{|c|}{ Diffuse $\left[\mathrm{kWh} / \mathrm{m}^{2}\right]$} \\
\hline \multicolumn{2}{|l|}{ January } & \multicolumn{2}{|r|}{2.85} & \multicolumn{2}{|r|}{1.07} \\
\hline \multicolumn{2}{|c|}{ February } & \multicolumn{2}{|r|}{3.54} & \multicolumn{2}{|r|}{1.34} \\
\hline \multicolumn{2}{|l|}{ March } & \multicolumn{2}{|r|}{4.76} & \multicolumn{2}{|r|}{1.64} \\
\hline \multicolumn{2}{|l|}{ April } & \multicolumn{2}{|r|}{6.08} & \multicolumn{2}{|r|}{1.88} \\
\hline \multicolumn{2}{|l|}{ May } & \multicolumn{2}{|r|}{6.98} & \multicolumn{2}{|r|}{2} \\
\hline \multicolumn{2}{|l|}{ June } & \multicolumn{2}{|r|}{7.77} & \multicolumn{2}{|r|}{1.87} \\
\hline \multicolumn{2}{|l|}{ July } & \multicolumn{2}{|r|}{7.53} & \multicolumn{2}{|r|}{1.86} \\
\hline \multicolumn{2}{|l|}{ August } & \multicolumn{2}{|r|}{6.67} & \multicolumn{2}{|r|}{1.8} \\
\hline \multicolumn{2}{|c|}{ September } & \multicolumn{2}{|r|}{5.7} & & 1.55 \\
\hline October & & & 4.17 & & 1.38 \\
\hline Novembe & & & 3.17 & & 1.1 \\
\hline Decembe & & & 2.63 & & 0.98 \\
\hline Year & & & 5.15 & & 1.54 \\
\hline
\end{tabular}

Figure 3. The irradiation/month of Amman

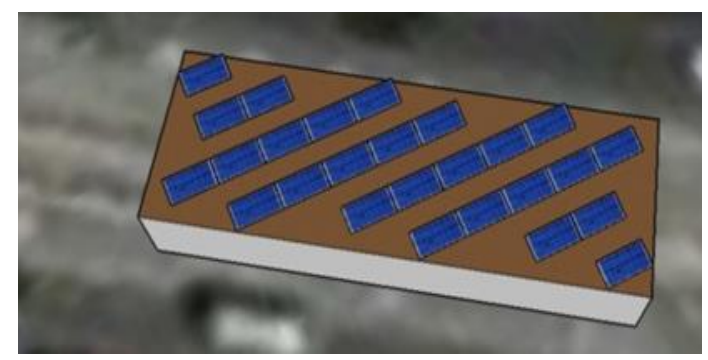

(A)

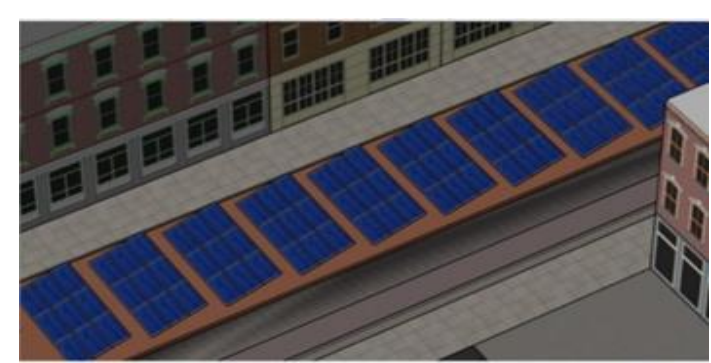

(B)

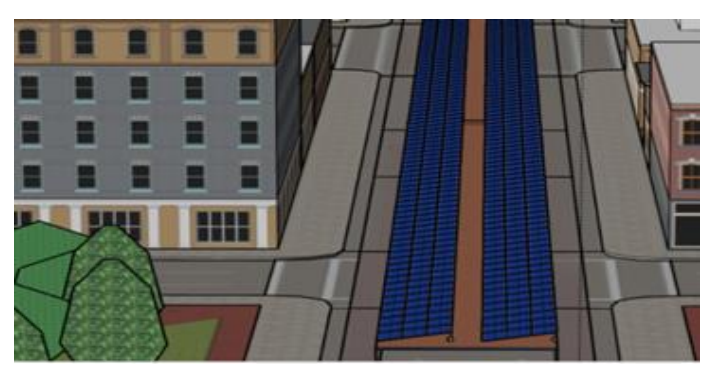

(C)

Figure 4. The proposed cases for the scale and structures of solar panels

\section{RESULTS AND ANALYSIS}

3.1. The energy consumption of the bus

The first step in determining the total energy consumption is decreasing the difference in elevation of each station at which the bus will stop, and calculate the energy consumption/produced by the bus, according to the following equations:

$$
k . e=\frac{1}{2} * m * \frac{v^{2}}{\mu}
$$

where k.e is the kinetic energy of the bus in Joules, $m$ is the mass of the bus $(20000 \mathrm{~kg}), \mathrm{v}$ is the velocity of the bus $(13.88 \mathrm{~m} / \mathrm{s})$ and $\mu$ is the efficiency of the bus. This value depends on the bus used. In the current investigation, $\mu$ was 0.85 . 
Energy consumption (in $\mathrm{KWH}, 1 \mathrm{KWH}=3600000 \mathrm{~J}$ ) is calculated form the following relation:

$$
\mathrm{E}=\left(\frac{K W H}{m i l e}\right) * \text { mile }
$$

The consumption /produced energy related to the elevations is obtained from the following equation:

$$
\mathrm{E}=m * g *\left(h_{2}-h_{1}\right) * 0.3
$$

where $g$ is the gravity, $h_{1}$ and $h_{2}$ are the initial and final elevations, respectively. The constant $(0.3)$ is the regenerative breaking factor of the bus. The regenerative breaking of the bus is could be obtained from the relation:

$$
\mathrm{E}=\frac{1}{2} * m * v^{\wedge} 2 * 0.3
$$

\subsection{Charge and charge time}

After the bus has reached many cycles which consumed $80 \%$ of the total energy where the battery should be recharged when it is under $20 \%$. It must recharge again to continue the service and from the following, we can calculate [3]:

a) The maximum available time (t_a) to recharge:

$$
\mathrm{t} \_\mathrm{a}=\operatorname{Re} * \text { Troute }
$$

where the $\mathrm{t} \_\mathrm{a}$ is the time in hour, $R e$ is the operation routs or the cycles of one route, Route is the energy consumed for one route.

b) The required charging time (t_chg) is:

$$
\mathrm{t} \_ \text {ch }=\mathrm{Re} * \frac{\text { Eroute }}{\text { Pch }}
$$

where $t$ is the external charging power of the battery.

c) The required number of the buses $(\mathrm{Nc})$ :

$$
\mathrm{Nc}=\frac{\text { Trtot }}{\text { Tin }}
$$

where Trtot is the total time to pass the distance and the minimum waiting time was defined to be 5 minutes.

Table 3. Total time for each phase

\begin{tabular}{cc}
\hline Phase & Total time of the distance \\
\hline Phase one & 29.2 \\
Phase tow & 30 \\
Phase three & 30 \\
\hline
\end{tabular}

Table 4. Result of analysis

\begin{tabular}{cccc}
\hline Phase & Phase 1 & Phase 2 & Phase3 \\
\hline$N_{c}$ & 6 & 6 & 6 \\
$T_{c h}$ & 5 & 5 & 5 \\
$T_{a}$ & 10.2 & 10.5 & 12.0 \\
$E_{\text {rout }} \mathrm{kwh}$ & 27.880 & 28.060 & 25.198 \\
$R_{e}$ & 23 & 23 & 26 \\
$R_{e}$ & 21 & 22 & 24 \\
$P_{c h} \mathrm{kw}$ & 120 & 120 & 120 \\
\hline
\end{tabular}




\section{CONCLUSION}

The photovoltaic system is a perfect technology to produce an electrical power senario to operate the high - frequency speed buses in addition to another benefit of service. To generate power exceeds 18 megawatts, there is need to use most of the area of the bus paths up to $126 \mathrm{~km}^{2}$, arrange the panels with streets scale produced an azimuth angle ranging between $0^{\circ}-90^{\circ}$ and the best tilt angle was measured as $12^{\circ}$ although the power doesn't go down very much, The areas of the route that have a shadow effecting at the cell's production even reached to $18 \mathrm{~km}$ out of $25 \mathrm{~km}$. Consumption energy of the buses vary upon the difference of elevation and number of stopping at the stations.

\section{REFERENCES}

[1] A. Al-Rawashdeh A., "Simulation and Analysis of the possibilities of traction electric motor," Indonesian Journal of Electrical Engineering and Computer Science, vol/issue: 14(1), 2019.

[2] A. Samarah, "A Comparative Study of Single Phase Grid Connected Phased Locked Loop Algorithms," Jordan Journal of Mechanical and Industrial Engineering (JJMIE), vol/issue: 11(3), pp. 185-194, 2017.

[3] Kakuhama Y., et al., "Next-generation Public Transportation: Electric Bus Infrastructure Project," Mitsubishi Heavy Industries Technical Review, vol/issue: 48(1), pp. 1-4, 2011.

[4] M. G. Richter and H. Koch H., "6th Transport Research Arena April 18-21, 2016 Electrification of public transport in cities (Horizon 2020 ELIPTIC Project)," Transport Research Arena, vol. 14, pp. 2614-2619, 2016.

[5] J. Q. Li, "Battery-electric transit bus developments and operations: A review," International Journal of Sustainable Transportation, vol/issue: 10(3), pp. 157-169, 2016.

[6] J. Kim, et al., "An Electric Bus with a Battery Exchange System,” Energies, vol. 8, pp. 6806-6819, 2015.

[7] L. Khirfan, "From Toronto to Amman: The Cross-National Transfer of Planning Knowledge," Planning Theory \& Practice, vol/issue: 12(4), pp. 525-547, 2011.

[8] G. A. Municipality, "BRT project design," 2015. Available at http://www.ammanbrt.jo/en/default.asp. 